\title{
ANÁLISIS FARMACOCINÉTICO Y ADMINISTRACIÓN EXTRAVASCULAR; ERRORES COMUNES EN EL CÁLCULO Y LA INTERPRETACIÓN DE LOS PARÁME- TROS FARMACOCINÉTICOS
}

\author{
Reutemann, S. H. ${ }^{1}$ \& Formentini, E. A. $^{2}$
}

\begin{abstract}
RESUMEN
Un estudio farmacocinético tiene por objeto conocer el comportamiento de una molécula una vez que esta ha sido introducida en un organismo. Por definición, la farmacocinética estudia la velocidad a la que se producen los procesos de absorción, distribución y eliminación y que son expresados matemáticamente en términos de constantes de velocidad. Los estudios farmacocinéticos conducidos por las vías intravascular y extravascular son complementarios. El estudio de la distribución y la eliminación de un medicamento se realiza a partir de los perfiles obtenidos tras su administración intravascular, mientras que la administración extravascular permite estimar el orden y la velocidad del proceso de absorción y la fracción de la dosis administrada que ha ingresado al organismo. En este artículo se presentan los errores que corrientemente se cometen al calcular e interpretar los parámetros farmacocinéticos obtenidos en un estudio extravascular sin considerar la información generada por un estudio intravascular. Por otra parte, la importancia de los parámetros farmacocinéticos obtenidos a partir de un estudio intravascular en el diseño de los regímenes terapéuticos es discutida.

Palabras clave: farmacocinética, terapéutica, intravascular, extravascular, regímenes terapéuticos.
\end{abstract}

\section{SUMMARY}

\section{Pharmacokinetic analysis and extravascular drug administration; com- mon errors in the calculation and interpretation of the kinetic parameters}

A pharmacokinetic study aims at the knowledgement of the behaviour of a molecule once it has been introduced in the organism. By definition, pharmacokinetics investigates the rate at which the processes of absorption, distribution and elimination take place, and how these processes are expressed mathematically in terms of rate constants. The pharmacokinetic trials performed by intravascular and extravascular administration of any drug are complementary, since the study of the distribution

1.- Alumna de la carrera de Medicina Veterinaria. Pasante de la Cátedra Farmacología. Facultad de Ciencias Veterinarias, UNL. Kreder 2805. (3080) Esperanza, provincia de Santa Fe. Tel: (03496) 420639.

2.- Doctor en Ciencias Veterinarias. Cátedra de Farmacología, Facultad de Ciencias Veterinarias, UNL

Manuscrito recibido el 7 de abril de 2004 y aceptado para su publicación el 4 de agosto de 2004. 
and the elimination of the drug is carried out from the plasma concentration profiles obtained after intravascular administration, while the extravascular administration of a drug allows to estimate the order and the rate of the absorption process and the fraction of the administered dose that reaches the systemic circulation. In this article are presented the common errors that currently occur when the pharmacokinetic parameters obtained from an extravascular study are calculated and interpreted without consideration of the information generated by the intravascular study. Moreover, the importance of the pharmacokinetic parameters obtained from an intravascular study in the development of therapeutic dosage regimens will be discussed.

Key words: pharmacokinetics, therapeutics, intravascular, extravascular, dosage regimens 